\title{
STRATEGI LAPORAN KEUANGAN PADA USAHA MIKRO KECIL DAN MENENGAH
}

\author{
Fitria Setyaningrum ${ }^{1}$ Maria Yunista ${ }^{2}$ \\ ${ }^{1)}$ Staf Pengajar Program Studi Manajemen Fakultas Ekonomi Universitas Tribhuwana Tunggadewi \\ ${ }^{2)}$ Mahasiswa Program Studi Manajemen Fakultas Ekonomi Universitas Tribhuwana Tunggadewi
}

\begin{abstract}
ABSTRAK
Pengelolaan keuangan menjadi suatu masalah dalam UMKM karena pemilik UMKM mengabaikan pentingnya pengelolaan laporan keuangan. Tujuan dari penelitian ini adalah: 1) untuk mengetahui seberapa jauh pemahaman pelaku UMKM di Tlogomas Malang terhadap pencatatan keuangan 2) untuk menambah strategi terbaru laporan keuangan pada pelaku UMKM. Penelitian ini dilakukan di Kelurahan Tlogomas, Kecamatan Lowokwaru Kabupaten Malang pada bulan November-Desember 2017. Sasaran penelitian yang dipilih yaitu para pelaku UMKM pada kelurahan Tlogomas Malang. Penelitian ini merupakan penelitian kualitatif dengan teknik pengumpulan data dilakukan melalui obervasi, wawancara, dokumentasi dan triangulasi. Teknik analisis data menggunakan analisis SWOT. Hasil penelitian menunjukan bahwa: 1) pelaku UMKM di Tlogomas Malang telah mengelompokkan transaksi sesuai akun-akun yang ada didalam laporan keuangan yang dilihat berdasarkan pencatatan keuangan yang dilakukan dalam usahanya sehingga dapat dikatakan mampu mencapai tingkat penafsiran tetapi belum mencapai tingkat ekstrapolasi karena pelaku UMKM di Tlogomas Malang hanya melakukan pencatatan keuangan dalam bentuk yang sederhana. 2) strategi baru yang dapat digunakan oleh pelaku UMKM dalam mencatat laporan keuangan adalah dengan bantuan layanan software Microsoft Excel. 3) strategi yang digunakan dalam mengelola laporan keuangan pada pelaku UMKM di Tlogomas Malang berdasarkan analisa SWOT adalah strategi konsentrasi melalui integrasi horizontal. Artinya strategi yang diterapkan lebih defensif, yaitu pelaku UMKM cenderung lebih survival.
\end{abstract}

Kata kunci: Laporan Keuangan, UMKM

\section{PENDAHULUAN}

Berdasarkan data yang diperoleh dari Kementrian Koperasi dan Usaha Mikro Kecil dan Menengah (UMKM) menunjukkan bahwa jumlah UMKM di Indonesia pada tahun 2013 adalah lebih kurang 57 juta unit, sedangkan jumlah usaha besar adalah 5.066 unit. Pada periode tahun 2012-2013 menunjukkan bahwa ada peningkatan jumlah unit usaha sebesar 2,41\%, sedangkan persentase kenaikan untuk usaha besar hanya 1,97\%. Data tersebut menunjukkan bahwa jumlah UMKM lebih besar bila dibandingkan dengan jumlah usaha besar yang ada di Indonesia. Data ini membuktikan bahwa
UMKM merupakan penyokong perekonomian Indonesia.

UMKM sebagai penyokong perekonomian, juga dapat dilihat melalui flashback pada peristiwa di tahun 1997 hingga tahun 1998, yaitu adanya krisis ekonomi. Peristiwa krisis ekonomi ini membuat banyak perusahaan besar yang bangkrut. Namun UMKM tetap dapat bertahan dari gejolak krisis yang terjadi. Selain itu, UMKM juga memberikan kontribusi Produk Domestik Bruto (PDB) yang besar yaitu sekitar satu milyar setiap tahunnya. Berdasarkan data yang diperoleh dari Kementrian Koperasi dan UMKM bahwa persentase PDB UMKM pada tahun 2010- 
2013 terus mengalami kenaikan tiap tahunnya. Data- data tersebut menandakan bahwa UMKM perlu untuk mempertahankan eksistensi, dan mengembangkan usahanya.

Namun pada kenyataannya masih ada UMKM yang belum mampu mengelola usahanya dengan baik, sehingga tidak jarang pula UMKM yang gagal dalam usahanya. Kegagalan ini disebabkan karena masih rendahnya pengetahuan pemilik UMKM akan pengelolaan usaha. Pengelolaan usaha yang perlu diperhatikan adalah pengelolaan dalam bidang keuangan. Namun, menurut Srikandi dan Setyawan (2004), masalah yang sering dihadapi pemilik UMKM adalah dalam bidang pemasaran produk, teknologi, kualitas sumber daya manusia, dan pengelolaan keuangannya. Pengelolaan keuangan menjadi suatu masalah dalam UMKM karena pemilik UMKM mengabaikan pentingnya pengelolaan keuangan.

Pengelolaan keuangan penting untuk diterapkan pada UMKM. Menurut Ediraras (2010) bisnis UMKM yang keuangannya dikelola dan diinformasikan secara transparan dan akurat akan memberikan dampak positif terhadap bisnis UMKM itu sendiri. Dampak positif pengelolaan keuangan inilah, yang menjadi suatu faktor kunci keberhasilan UMKM dan dapat digunakan untuk mempertahankan keberlanjutan usahanya. Salah satu jenis UMKM adalah UMKM makanan dan minuman. Kabupaten Malang memiliki UMKM makanan dan minuman, yang kualitas produknya tidak kalah bersaing dengan produk makanan dan minuman dari daerah lain di Yogyakarta. Berdasarkan hasil observasi yang dilakukan pada Asosiasi ini masih terdapat masalah yang timbul, yaitu pengelolaan usaha yang dilakukan hanya berfokus kepada pemasaran, dan mengesampingkan pengelolaan keuangannya.

Berdasarkan pemaparan latar belakang tersebut, penulis tertarik untuk mengambil judul tentang "STRATEGI LAPORAN KEUANGAN PADA USAHA MIKRO KECIL DAN MENENGAH PADA PELAKU UMKM MAKANAN DAN MINUMAN TLOGOMAS MALANG”. Penelitian ini penting dilakukan untuk mengetahui pengelolaan keuangan apa saja yang telah diterapkan pada UMKM. Hasil dari penelitian ini juga dapat dijadikan sebagai pedoman, apabila UMKM tesebut belum menerapkan pengelolaan keuangan.

\section{METODE PENELITIAN}

\section{Lokasi dan Waktu Penelitian}

Penelitian ini dilakukan di Kelurahan Tlogomas, Kecamatan Lowokwaru Kabupaten Malang pada bulan November 2017-Desember 2017. Sasaran penelitian yang dipilih yaitu para pelaku UMKM pada kelurahan Tlogomas Malang.

Penelitian ini merupakan penelitian kualitatif. Menurut Sugiyono (2013) menjelaskan penelitian kualitatif adalah penelitian yang digunakan untuk meneliti 
pada kondisi obyek alamiah, dimana peneliti adalah sebagai instrumen kunci, teknik pengumpulan data di lakukan secara trianggulasi (gabungan), analisis data bersifat induktif, dan hasil penelitian lebih menekankan makna dari pada generelasi.

Jenis dan sumber data yang digunakan dalam Penelitian ini adalah sebagai berikut:

1. Data Primer

Data primer yang dibutuhkan dalam penelitian ini meliputi profil pemilik, proses usaha, karakteristik UMKM, serta data yang berhubungan dengan pengelolaan keuangan. Data-data tersebut diperoleh melalui wawancara, Observasi, Dokumentasi dan triangulasi.

2. Data sekunder
Data sekundenr diperoleh dari buku yang berhubungan dengan pengelolaan laporan keuangan pada UMKM.

\section{HASIL DAN PEMBAHASAN \\ Profil UMKM}

Hasil dari beberapa informasi usaha mikro kecil dan menengah di kawasan Tlogomas Malang yang didapat, diperoleh tiga pelaku usaha kecil menengah makanan dan minuman yang memiliki pendapatan minimal usaha selama setahun adalah $\mathrm{Rp}$ 300.000.000,- (tiga ratus juta rupiah) yang merupakan ketentuan dari Undang-Undang nomor 20 tahun 2008 pendapatan untuk usaha bersakala kecil, dan lama usaha minimal selama 7 tahun, dan bersedia untuk diwawancarai dalam penelitian ini. Berikut daftar usaha kecil dan menengah yang bersedia diwawancarai:

Tabel 1. Daftar Usaha UMKM

\begin{tabular}{|c|l|l|l|l|}
\hline No & Nama UKM & Nama Pemilik & \multicolumn{1}{c|}{ Alamat } & \multicolumn{1}{c|}{ Bidang Usaha } \\
\hline 1 & Gloria & Ibu Lya & Jl. Tlogomas & Makanan dan minuman \\
\hline 2 & Ina & Ibu Ina & Jl. Tlogo Wulan & Makanan dan minuman \\
\hline 3 & Bismilah & Bapak Ahmad & Jl. Tlogomas & Makanan dan minuman \\
\hline
\end{tabular}

Sumber: Hasil Wawancara, Diolah

Peneliti mengumpulkan informasi dan data terkait dalam penelitian ini dari hasil wawancara yang telah dilakukan dengan informan dari masing-masing UKM. Dalam penelitian ini, pertanyaan semi terstruktur digunakan untuk memperoleh data dari informan terkait. Wawancara dengan pertanyaan semi terstruktur lebih memudahkan peneliti menentukan alur dalam mengumpulkan data yang dibutuhkan.
Sebelum melakukan wawancara, peneliti membuat janji terlebih dahulu, sehingga tidak mengganggu waktu kerja dan dapat melakukan wawancara lebih leluasa. Hal tersebut dimaksudkan agar informan dapat memberikan lebih banyak informasi yang penting dalam penelitian ini.

Hasil wawancara dengan pemilik UMKM Gloria yaitu Ibu Lya pada tanggal 23 
November 2017 jam 08.30 WIB menyatakan bahwa:

"UMKM Gloria merupakan UMKM yang bergerak dalam bidang usaha makanan dan minuman. UMKM ini didirikan pada tahun 2013. Sekarang UMKM Gloria sudah memiliki 7 orang pekerja dengan tugasnya masing-masing. Keuntungan perhari yang diperoleh dari usaha ini sebesar Rp. 900.000-"

Hasil wawancara dengan pemilik UMKM Ina yaitu Ibu Ina pada tanggal 24 November 2017 jam 08.00 WIB menyatakan bahwa:

"UMKM Ina memiliki keuntungan bersih perhari kira-kira Rp. 900.000-, per hari. Saya mendirikan UMKM ini pada tahun 2015. Usaha ini saya jalankan dengan menggunakan modal sendiri. Saya dibantu oleh 2 orang saudara dalam menjalankan usaha ini."

Hasil wawancara dengan pemilik UMKM Bismilah yaitu Bapak Ahmad pada tanggal 25 November 2017 jam 08.30 WIB ia menyatakan bahwa:
"Kalau pendapatan UMKM ini perbulanya sekitar Rp. 22.000.000-,. UMKM Gloria didirikan pada tahun 2008. Sampai sekarang jumlah pekerja saya 4 oramg yang terdiri dari bagian keuangan, pemasaran, cleaning dan gudang. Tugas saya dalam usaha ini sebagai pemilik dan sekaligus bagian produksi. Modal yang digunakan dalam usaha ini merupakan modal pribadi."

\section{Pemahaman Pelaku UMKM Di Tlogomas}

\section{Malang terhadap Pencatatan Keuangan}

Masing-masing pelaku usaha memiliki pemahaman berbeda-beda mengenai laporan keuangan. Hal tersebut ditunjukkan dari hasil wawancara dengan masing-masing informan. Dalam pemahamannya mengenai nama-nama akun yang dipahami masing-masing usaha, pemahaman disesuaikan dengan pengetahuan serta keadaan yang ada dalam kegiatan usaha sehari-hari. Hasil wawancara tentang pemahaman UMKM terhadap pencatatan keuangan dapat disajikan pada Tabel 2.

Tabel 2. Pemahaman UMKM Terhadap Pencatatan Keuangan

\begin{tabular}{|c|c|c|c|c|}
\hline \multirow{2}{*}{ No } & \multirow{2}{*}{ Tingkat Pemahaman } & \multicolumn{3}{|c|}{ Nama Informan/UMKM } \\
\cline { 3 - 5 } & & Gloria & Ina & Bismilah \\
\hline 1 & Terjemahan & $\checkmark$ & $\checkmark$ & $\checkmark$ \\
\hline 2 & Penafsiran & $\checkmark$ & $\checkmark$ & $\checkmark$ \\
\hline 3 & Ekstrapolasi & $\checkmark$ & - & - \\
\hline
\end{tabular}

Sumber: Hasil Wawancara, Diolah

Tabel di atas menggambarkan pemahaman para pelaku usaha terhadap laporan keuangan berdasarkan tingkat pemahaman. Tingkat pemahaman dibagi menjadi tiga tingkatan yaitu tingkat terjemahan, tingkat penafsiran, dan tingkat ekstrapolasi. 
Dari hasil wawancara dan observasi yang telah dilakukan, didapatkan bahwa ketiga informan mampu dalam memberikan pemahamannya dalam mengartikan dan mendefinisikan beberapa akun dalam laporan keuangan. Informan dari masing-masing usaha memberikan penjelasan mengenai beberapa nama akun yang mereka pahami. Pengetahuan pelaku usaha dalam memahami bagian-bagian laporan keuangan tersebut disesuaikan dengan kegiatan usaha seharihari. Seperti akun kas yang ditarik kesimpulannya merupakan uang tunai yang dipegang dalam usaha baik dari hasil penjualan tunai, maupun kas keluar untuk memenuhi kebutuhan usaha. Atau akun persediaan yang merupakan stok bahan yang tersedia, baik stok bahan baku maupun stok barang yang sudah jadi. Hal tersebut menyiratkan bahwa ketiga informan mampu mencapai pada tingkat terjemahan.

Tingkat selanjutnya yaitu tingkat penafsiran yang mana para pelaku usaha diharapkan mampu mengelompokkan bagianbagian terkecil yang kemudian membentuk akun maupun bagian laporan keuangan lainnya. Pada tingkat penafsiran, ketiga informan mampu mengelompokkan transaksitransaksi yang terjadi berdasarkan akun-akun tertentu dalam laporan keuangan. Pada tingkat ini pemahaman pelaku usaha dalam menafsirkan laporan keuangan ditunjukkan dengan cara bagaimana menghitung harga pokok produksi. Jika disimpulkan pemahaman pelaku usaha dalam membentuk harga pokok produksi terdiri dari biaya bahan utama, biaya tenaga kerja langsung serta biaya overhead pabrik.

Selanjutnya adalah tingkat ektrapolasi, dimana tingkat ini diharapkan para pelaku usaha mampu memprediksi, mengestimasi berdasarkan pada pengertian dan kondisi yang disajikan ke dalam bentuk ide-ide maupun simbol-simbol serta memahami keterkaitan bagian-bagian laporan keuangan. Berdasarkan pemahaman pelaku UMKM di Tlogomas pada tingkat ektrapolasi dapat diketahui bahwa satu informan mampu menunjukkan contoh membuat bagian laporan keuangan yang berdasarkan standar akuntansi keuangan yang berlaku. Hal tersebut didukung dengan adanya bagian akuntan dalam kegiatan usaha, sehingga membantu dalam membuat laporan keuangan walaupun tidak dilakukan secara konsisten setiap periode yang ditentukan. Satu informan belum melakukan laporan keuangan dengan alasan waktu yang tidak sempat serta kurangnya pemahaman dalam menyusun laporan keuangan berdasarkan standar yang berlaku. Satu informan berikutnya membuat laporan keuangan, namun masih jauh dari kesesuaiannya dengan laporan keuangan yang berdasarkan standar akuntansi. Karena dalam menyusun laporan keuangan hanya terdiri dari hasil penjualan, biaya dalam membuat produksi, serta biaya-biaya lain yang dikeluarkan selama kegiatan usaha. Hal ini menunjukkan bahwa hanya satu informan 
yang mampu menyajikan bagian laporan keuangan sesuai dengan standar akuntansi.

\section{Strategi Terbaru Laporan Keuangan Pada Pelaku UMKM}

Pada UMKM makanan dan minuman seperti Gloria, Ina dan Bismilah sudah selayaknya membuat laporan keuangan yang sesuai dengan pedoman akutansi, agar mengetahui kebenaran aset yang dimiliki usahanya serta mengetahui hutang yang dimiliki pada pihak eksternal, untuk memastikan perkembangan usaha dengan baik bukan hanya melihat dari segi kinerja karyawan ataupun target penjualan barang, akan tetapi yang paling penting adalah memperhatikan kondisi keuangan yang sesungguhnya.

Para pelaku UMKM Gloria, Ina dan Bismilah hanya mencatat laporan keuangan dengan sederhana saja, seperti hanya mencatatkan uang masuk dan uang keluar, lalu para pelaku menselisihkan antara uang masuk dan uang keluar, dari hasil itulah yang pelaku UMKM anggap sebagai laba. Selain itu, usaha yang sudah berjalan bertahun-tahun pun ada juga yang mencatat penghasilan harian, tanpa adanya laporan yang jelas dan sesuai dengan pedoman akuntansi. Menurut Fitrianai Saragih dan Surikayanti (2015) pada dasarnya para pelaku UMKM tidak mengetahui pengetahuan dasar tentang akuntansi, karena proses akuntansi yang di jalankan dalam usaha dilakukan oleh pegawai. Sehingga, para pelaku UMKM tidak dapat membaca laporan yang disajikan oleh pegawainya. Banyak resiko yang didapat jika pelaku UMKM hanya melakukan pencatatan secara standar atau para pelaku tidak bisa membaca laporan yang disajikan oleh pegawainya, yaitu dapat terjadinya kecurangan-kecurangan dalam pencatatan, resiko kerugian akibat kesalahan pencatatan, dan yang resiko yang paling fatal usaha yang dijalani sampai gulung tikar. Sehingga dari laporan keuangan yang sederhana tanpa mengacu pada pedoman akuntansi membuat pelaku UMKM akan mengambil keputusan yang asal dan tanpa alasan yang kuat dan tepat.

Strategi baru yang dapat digunakan oleh pelaku UMKM di Tlogomas Malang dalam mencatat laporan keuangan adalah dengan bantuan layanan software. Cara ini akan memudahkan pelaku UMKM di Tlogomas Malang dalam melakukan perhitungan laporan keuangan secara otomatis.

Microsoft Excel (MS-Excel) adalah suatu program aplikasi lembar kerja elektronik yang canggih dan mudah dioperasikan. Microsoft excel juga sangat populer digunakan oleh masyarakat saat ini. Microsoft Excel sangat membantu dalam hal menghitung, memproyeksikan, menganalisa, dan dapat juga membantu mempresentasikan data dalam bentuk chart maupun berbagai macam tabel. Microsoft excel juga mudah diintegrasikan dengan program Microsoft 
office lainnya, bahkan program yang memiliki fungsi berbeda. Microsoft Excel juga memiliki kemampuan untuk berhubungan dengan internet. Melihat fungsi Microsoft Excel yang dapat membantu dalam hal menghitung sampai pada kemampuannya dalam mempresentasikan data dalam bentuk informasi, maka hal ini dapat membantu juga dalam sistem akuntansi. Bahkan melaui Microsoft Excel, laporan keuangan dapat disusun secara sederhana dengan siklus yang lebih pendek yaitu dari penyusunan jurnal menjadi laporan keuangan sederhana.

\section{Analisis SWOT Untuk Menentukan}

Strategi Laporan Keuangan Pada Pelaku

\section{UMKM}

Aspek Internal

Aspek internal diperoleh dari penggunaan anggaran, pencatatan, pelaporan dan pengendalian. Aspek internal dibedakan menjadi kekuatan dan kelemahan yang terdapat pada pelaku UMKM di Tlogomas Malang. Faktor kekuatan dan kelemahan ditentukan berdasarkan hasil analisis, observasi dan wawancara, dari pelaku UMKM di Tlogomas Malang. Rating dan bobot dihasilkan melalui penilaian prioritas dari hasil wawancara dan observasi.

Faktor strategi internal dan hasil penilaian bobot dan rating dari faktor internal pelaku UMKM di Tlogomas Malang dijelaskan pada tabel berikut.

Tabel 4. Faktor-Faktor Strategi Internal

\begin{tabular}{|c|c|c|c|}
\hline Faktor & Bobot & Rating & Skor \\
\hline Kekuatan & & & \\
\hline $\begin{array}{l}\text { 1. Modal awal yang digunakan untuk membuka usaha adalah } \\
\text { dari tabungan pribadi }\end{array}$ & 0.20 & 4 & 0.80 \\
\hline 2. Mencatat transaksi penerimaan dan pengeluaran kas & 0.10 & 2 & 0.20 \\
\hline 3. Membuat laporan laba rugi & 0.15 & 3 & 0.45 \\
\hline $\begin{array}{l}\text { 4. Mengarsipkan nota dari penggunaan kas yang telah } \\
\text { dikeluarkan }\end{array}$ & 0.10 & 2 & 0.20 \\
\hline Total skor kekuatan & & & 1.65 \\
\hline Kelemahan & & & \\
\hline 1. Manajemen persediaan bahan baku belum teratur & 0.05 & 4 & 0.20 \\
\hline $\begin{array}{l}\text { 2. Rendahnya sumber daya manusia yang memungkinkan } \\
\text { untuk melakukan pencatatan transaksi }\end{array}$ & 0.10 & 3 & 0.30 \\
\hline 3. Penyusunan laporan keuangan sederhana & 0.20 & 1 & 0.20 \\
\hline 4. Tidak ada pengendalian operasi & 0.10 & 3 & 0.30 \\
\hline Total skor kelemahan & & & 1.00 \\
\hline Total & 1.00 & & 2.65 \\
\hline
\end{tabular}

Aspek Eksternal

Faktor strategi eksternal suatu perusahan diidentifikasi dan disusun untuk merumuskan faktor strategi eksternal perusahan. Aspek eksternal dibedakan menjadi peluang dan ancaman yang terdapat pada pelaku UMKM di Tlogomas Malang. Faktor peluang dan ancaman ditentukan 
berdasarkan hasil analisis, observasi dan wawancara, dari pelaku UMKM di Tlogomas Malang. Rating dan bobot dihasilkan melalui penilaian prioritas dari hasil wawancara dan observasi.
Faktor strategi eksternal dan hasil penilaian bobot dan rating dari faktor internal pelaku UMKM di Tlogomas Malang dijelaskan pada tabel berikut.

Tabel 5. Faktor-Faktor Strategi Eksternal

\begin{tabular}{|c|c|c|c|}
\hline Faktor & Bobot & Rating & Skor \\
\hline Peluang & & & \\
\hline 1. Minat investor untuk menanam modal & 0.10 & 2 & 0.20 \\
\hline 2. Program pelatihan dan pendampingan dari pemerintah & 0.20 & 4 & 0.80 \\
\hline 3. Teknologi informasi yang semakin canggih & 0.15 & 3 & 0.45 \\
\hline 4. Pinjaman dari pihak lain (Pihak Bank) & 0.05 & 1 & 0.05 \\
\hline Total skor peluang & & & 1.50 \\
\hline Ancaman & & & \\
\hline 1. Meningkatnya biaya produksi & 0.05 & 4 & 0.20 \\
\hline 2. Pesaing baru terus bermunculan & 0.20 & 1 & 0.20 \\
\hline 3. Besaran kewajiban membayar pajak yang tidak diketahui & 0.15 & 2 & 0.30 \\
\hline 4. Tidak memiliki kreditor yang bersedia memberi pinjaman & 0.10 & 3 & 0.30 \\
\hline Total skor ancaman & & & 1.00 \\
\hline Total & 1.00 & & 2.50 \\
\hline
\end{tabular}

Internal-Eksternal Matrik

Dari total skor yang diperoleh, yaitu faktor strategi internal 2,65 dan faktor strategi eksternal 2,50 menunjukan titik koordinat terletak pada daerah pertumbuhan stabilitas (V) seperti ditunjukan pada Gambar InternalEksternal Matrik, dalam kasus ini berarti strategi pemecahan masalah harus melalui integrasi horizontal.

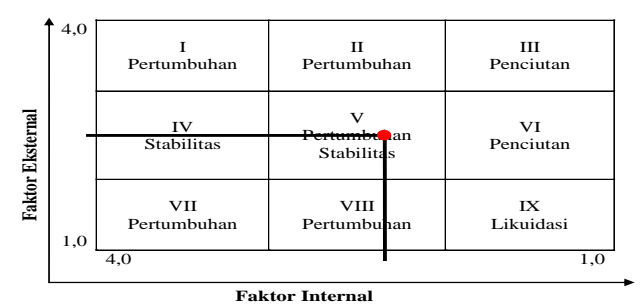

Gambar 3. Kondisi Internal-Eksternal Matrik Keterangan:

I : Strategi konsentrasi melalui integrasi vertical
II : Strategi konsentrasi melalui integrasi horizontal

III : Strategi turnaround

IV : Strategi stabilitas

$\mathrm{V}$ : Strategi konsentrasi melalui integrasi horizontal atau stabilitas

VI : Strategi divestasi

VII : Strategi diversifikasi

VIII : Strategi diversifikasi konsentrik

IX : Strategi likuiditas

Pada matriks di atas, dapat diketahu bahwa skor yang didapat dari faktor strategi internal sebesar 2,65 dan faktor strategi eksternal sebesar 2,50 yang mana titik koordinat terletak pada daerah pertumbuhan V. Sehingga strategi yang tepat untuk digunakan dalam mengelola laporan keuangan pada pelaku UMKM di Tlogomas 
Malang adalah strategi konsentrasi melalui integrasi horizontal. Artinya strategi yang diterapkan lebih defensif, yaitu pelaku UMKM di Tlogomas Malang cenderung lebih survival. Kelangsungan laporan keuangan pada pelaku UMKM lebih cenderung untuk bertahan dan tidak memiliki kemampuan untuk mengembangkan usahanya.

Analisa Matriks SWOT
Matrik SWOT digunakan untuk mengembangkan empat tipe alternatif strategi yaitu SO (strengths-opportunities), strategi WO (weaknesses-opportunities), strategi ST (strength-threats), dan strategi WT (weaknesses-threats). Berikut dapat disajikan hasil EFAS dan IFAS dapat digambarkan strategi yang harus dilakukan oleh pelaku UMKM. Berikut adalah Tabel Analisis Strategi Matriks SWOT.

Tabel 6. Analisis Matriks SWOT

\begin{tabular}{|c|c|c|}
\hline IFAS & STRENGHT (S) & WEAKNESS (W) \\
\hline & $\begin{array}{l}\text { 1. Modal awal yang digunakan } \\
\text { untuk membuka usaha adalah dari } \\
\text { tabungan pribadi } \\
\text { 2. Mencatat transaksi penerimaan } \\
\text { dan pengeluaran kas } \\
\text { 3. Membuat laporan laba rugi } \\
\text { 4. Mengarsipkan nota dari } \\
\text { penggunaan kas yang telah } \\
\text { dikeluarkan }\end{array}$ & $\begin{array}{l}\text { 1. Manajemen Persediaan } \\
\text { Bahan Baku Belum } \\
\text { Teratur } \\
\text { 2. Rendahnya sumber daya } \\
\text { manusia yang } \\
\text { memungkinkan untuk } \\
\text { melakukan pencatatan } \\
\text { transaksi } \\
\text { 3. Penyusunan laporan } \\
\text { keuangan sederhana } \\
\text { 4. Tidak ada pengendalian } \\
\text { operasi }\end{array}$ \\
\hline \multicolumn{3}{|l|}{ EFAS } \\
\hline OPPORTUNITY (O) & STRATEGI SO & STRATEGI WO \\
\hline $\begin{array}{l}\text { 1. } \begin{array}{l}\text { Minat investor untuk } \\
\text { menanam modal }\end{array} \\
\text { 2. Program pelatihan } \\
\text { dan pendampingan } \\
\text { dari pemerintah } \\
\text { 3. Teknologi informasi } \\
\text { yang semakin } \\
\text { canggih } \\
\text { 4. Pinjaman dari pihak } \\
\text { lain (Pihak Bank) }\end{array}$ & $\begin{array}{l}\text { 1. Pengoptimalan pengelolaan usaha } \\
\text { dengan menambah modal dari } \\
\text { pihak investor sehingga barang } \\
\text { yang dihasilkan lebih maksimal } \\
\text { 2. Program pelatihan dari } \\
\text { pemerintah guna menambah } \\
\text { pengetahuan tentang laporan } \\
\text { keuangan } \\
\text { 3. Membuat laporan keuangan } \\
\text { dengan bantuan teknologi } \\
\text { informasi } \\
\text { 4. Mengarsipkan nota guna } \\
\text { menambah pinjaman dari pihak } \\
\text { lain }\end{array}$ & $\begin{array}{l}\text { 1. Pelatihan manajemen } \\
\text { kepada pemilik usaha } \\
\text { yang dilakukan secara } \\
\text { berkelanjutan agar usaha } \\
\text { berkembang } \\
\text { 2. Melakukan pengendalian } \\
\text { terhadap harta, hutang dan } \\
\text { modal }\end{array}$ \\
\hline TREATH $(\mathrm{T})$ & STRATEGI ST & STRATEGI WT \\
\hline $\begin{array}{l}\text { 1. Meningkatnya biaya } \\
\text { produksi } \\
\text { 2. Pesaing baru terus }\end{array}$ & $\begin{array}{l}\text { 1. Membuat perencanaan guna } \\
\text { mengendalikan pengeluaran kas } \\
\text { 2. Mempertahankan kualitas produk }\end{array}$ & $\begin{array}{l}\text { 1. Menciptakan inovasi } \\
\text { produk agar memiliki daya } \\
\text { tarik yang tinggi }\end{array}$ \\
\hline
\end{tabular}




\begin{tabular}{|c|c|c|}
\hline $\begin{array}{ll}\text { bermunculan } \\
\text { 3. } & \begin{array}{l}\text { Besaran kewajiban } \\
\text { membayar pajak }\end{array} \\
\text { yang tidak diketahui } \\
\text { 4. } & \text { Tidak memiliki } \\
\text { kreditor yang } \\
\text { bersedia memberi } \\
\text { pinjaman }\end{array}$ & $\begin{array}{l}\text { agar mampu bersaing, Memutar } \\
\text { arus kas }\end{array}$ & $\begin{array}{l}\text { 2. Menambah karyawan } \\
\text { yang paham akan } \\
\text { manajemn keuangan }\end{array}$ \\
\hline
\end{tabular}

\section{KESIMPULAN}

Berdasarkan hasil penelitian dan pembahasan yang dilakukan sebelumnya maka dapat ditarik beberapa kesimpulan sebagai berikut:

1. Pelaku UMKM di Tlogomas Malang telah mengelompokkan transaksi sesuai akunakun yang ada didalam laporan keuangan yang dilihat berdasarkan pencatatan keuangan yang dilakukan dalam usahanya sehingga dapat dikatakan mampu mencapai tingkat penafsiran tetapi belum mencapai tingkat ekstrapolasi karena pelaku UMKM di Tlogomas Malang hanya melakukan pencatatan keuangan dalam bentuk yang sederhana.

2. Strategi baru yang dapat digunakan oleh pelaku UMKM dalam mencatat laporan keuangan adalah dengan bantuan layanan software Microsoft Excel.

3. Strategi yang digunakan dalam mengelola laporan keuangan pada pelaku UMKM di Tlogomas Malang berdasarkan analisa SWOT adalah strategi konsentrasi melalui integrasi horizontal. Artinya strategi yang diterapkan lebih defensif, yaitu pelaku UMKM cenderung lebih survival.

\section{DAFTAR PUSTAKA}

Ediraras, Tintri. 2010. "Akuntansi Dan Kinerja UKM" Jurnal Ekonomi Bisnis no. 2 Vol 15, Jakarta.

Saragih, Fitriani. Surikayanti. 2015. "Analisis Penerapan Akuntansi dan Keseuaiannya Dengan SAK ETAP pada UKM Medan Perjuangan" Jurnal: Universitas Muhammadiyah Sumatera Utara.

Srikandi, C. dan Setyawan, A.B. 2004 "Analisis Penerapan Siklus Akutansi pada Usaha Kecil Menengah di Daerah Istimewa Yogyakarta" Jurnal Ilmiah ESAY Vulume 9.

Sugiyono. 2013. Metode Penelitian Pendidikan Pendekatan Kuantitatif, Kualitatif, dan $R \& D$. Bandung: Alfabeta. 